\title{
Toxic Exposures
}




\section{Critical Issues in Health and Medicine}

Edited by Rima D. Apple, University of Wisconsin-Madison, and Janet Golden, Rutgers University, Camden

Growing criticism of the US healthcare system is coming from consumers, politicians, the media, activists, and healthcare professionals. Critical Issues in Health and Medicine is a collection of books that explores these contemporary dilemmas from a variety of perspectives, among them political, legal, historical, sociological, and comparative, and with attention to crucial dimensions such as race, gender, ethnicity, sexuality, and culture.

For a list of titles in the series, see the last page of the book. 


\section{Toxic Exposures}

\section{Mustard Gas and the Health \\ Consequences of World \\ War II in the United States}

Susan L. Smith

il

Rutgers University Press

New Brunswick, New Jersey, and London 
Library of Congress Cataloging-in-Publication Data

Names: Smith, Susan L., author.

Title: Toxic exposures : mustard gas and the health consequences of World War II in the United States / Susan L. Smith.

Description: New Brunswick, New Jersey : Rutgers University Press, [2017] I Series: Critical issues in health and medicine I Includes bibliographical references and index.

Identifiers: LCCN 2016015515 | ISBN 9780813586090 (hardback) | ISBN 9780813586113 (ebook (epub)) । ISBN 9780813586120 (e-book (web pdf))

Subjects: LCSH: Mustard gas-Toxicology. I Chemical weapons-United States-Testing. I Gases, Asphyxiating and poisonous. I BISAC: HISTORY / Military / Biological \& Chemical Warfare. I MEDICAL / History. I SCIENCE / History. I HISTORY / Military / World War II. I POLITICAL SCIENCE / Political Freedom \& Security / Human Rights. I HISTORY / United States / 20th Century.

Classification: LCC RA1247.M8 S65 2017 | DDC 615.9/1—dc23

LC record available at https://lccn.loc.gov/2016015515

A British Cataloging-in-Publication record for this book is available from the British Library.

Copyright () 2017 by Susan L. Smith

All rights reserved

No part of this book may be reproduced or utilized in any form or by any means, electronic or mechanical, or by any information storage and retrieval system, without written permission from the publisher. Please contact Rutgers University Press, 106 Somerset Street, New Brunswick, NJ 08901. The only exception to this prohibition is "fair use" as defined by U.S. copyright law.

Visit our website: http://rutgersuniversitypress.edu

Manufactured in the United States of America 
To Donald Macnab, for everything 
